\title{
TINGKAT LITERASI MAHASISWA FAKULTAS ILMU PENDIDIKAN UNIVERSITAS NEGERI JAKARTA TERHADAP MEDIA DAN INFORMASI (MEDIA AND INFORMATION LITERACY)
}

\author{
Lussy Dwiutami Wahyuni dan Evita Adnan
}

\begin{abstract}
Abstrak
University students should have ability in media and information literacy. Media and information literacy is skill to access, analyze, evaluate, and communicate information in several forms. Students know and understand information comprehensively to make up critical thingking : to analyze and evaluate the information. This research want to know about how is university student's media and information literacy.
\end{abstract}

Keywords : media, information, literacy, university student

\section{PENDAHULUAN}

Sebagaimana diketahui, peradaban masa depan adalah masyarakat informasi (information society), yaitu peradaban di mana informasi sudah menjadi komoditas utama dan interaksi antarmanusia sudah berbasis Teknologi Informasi dan Komunikasi (TIK). Selain itu, perkembangan teknologi informasi memacu suatu cara baru dalam kehidupan, dari awal hingga akhir kehidupan, kehidupan seperti ini dikenal dengan elife, artinya kehidupan ini sudah dipengaruhi oleh berbagai kebutuhan secara elektronik. Dewasa ini, sedang semarak dengan berbagai huruf yang dimulai dengan awalan " $e$ ", seperti e-commerce, e-government, e-education, e-library, e-journal, e-medicine, e-laboratory, e-biodiversity, dan lain-lain yang berbasis elektronika (Wardiana, 2002).

Seperti telah diungkapkan di atas, elektronik secara tidak langsung mempunyai peran strategis dalam mengembangkan masyarakat informasi. Hal ini dikarenakan elektronik bertindak sebagai perantara atau media yang membawa atau menyuarakan informasi dari pengirim ke penerima. Jadi, tidaklah mengherankan jika saat ini pertumbuhan informasi berbanding lurus dengan keberadaan media yang berkembang di masyarakat.

Antara media dan informasi bagai dua sisi mata uang yang saling berdekatan dan mempunyai hubungan simbiosis mutualisme (saling menguntungkan). Informasi akan mudah dan cepat tersampaikan dengan adanya campur tangan media. Media pun akan sedikit kehilangan giginya bila tidak ada yang disuarakannya. Jadi bisa dikatakan, media hadir untuk mempermudah dan mempercepat lajunya informasi sampai ke sasaran, sebaliknya informasi ada untuk mengisi media.

Untuk itu, guna menuju transformasi masyarakat menuju masyarakat informasi dan masyarakat berbasis pengetahuan, tidak saja membutuhkan infrastruktur (hardware, software, aplikasi, dan konektivitas/akses) yang handal dan regulasi (peraturan) yang mendukung, tetapi juga sumber daya manusia (SDM) atau brainware dengan tingkat literasi (melek) media yang memadai dan kemampuan mengeksplorasi isi dari sebuah informasi (literasi informasi) untuk menciptakan kemakmuran (depkominfo, 2007). Bahkan dalam sebuah papernya, Fasli Jalal dan Nina Sardjunani (dalam Isnaini, 2007) menghubungkan antara tingkat literasi dengan harapan hidup masyarakat. Ternyata ada korelasi yang positif antara keduanya, artinya semakin tinggi tingkat literasi sebuah masyarakat semakin tinggi pula harapan hidupnya.

Fenomena di atas akhirnya menimbulkan pelbagai paradigma baru dalam pendidikan. Pendidikan sebagai sarana belajar kian mendapatkan tantangan, ketika dihadapkan dengan zaman yang menurut para teorisi teknologi komunikasi (McLuhan dan Debray) dikenal sebagai "The Age of Media Society" (dalam Astuti, 2007).

Kampus sebagai salah satu produsen yang membidani terbentuknya sebuah masyarakat intelektual, sudah sepantasnya ikut mengambil bagian dalam pewujudan masyarakat informasi seperti yang telah diungkapkan di atas. Namun, tidak mudah untuk mewujudkan hal tersebut. Bukhori (2005) mengatakan, kendala yang melingkari terciptanya masyarakat literat ini tidak lain adalah sebagai berikut.

Pertama, budaya minat baca bangsa Indonesia masih tergolong rendah. Terbukti, kebanyakan orang merasa lebih berani merogoh saku lebih tebal untuk 
membeli kebutuhan lain, seperti makanan, pakaian, perhiasan, dan bahkan alat-alat rumah tangga, ketimbang membeli buku. Tingkat ekonomi yang rendah sering menjadi alasan lemahnya daya beli buku masyarakat. Oleh karena itu, banyak orang menjadi tidak akrab dan merasa asing dengan buku dan memiliki minat membaca yang rendah.

Kedua, karena adanya dampak negatif perkembangan teknologi bagi masyarakat. Masyarakat yang awalnya bertradisi lisan atau oral society, secara drastis bergerak ke budaya elektronik, seperti TV dan radio, sebelum memasuki budaya tulis secara ajeg. Banyak orang telah langsung melompat dari tradisi mendongeng ke tradisi menonton sebelum terbiasa dengan tradisi membaca.

Ditambah lagi, tipe pendidikan di Indonesia masih cenderung menganut interaksi satu arah dalam proses pembelajarannya. Dengan kondisi seperti ini, semakin mempertebal fakta bahwa keterampilan anak didik di Indonesia hanya sebatas sampai tataran menjadi pendengar yang baik saja. Terjadi demikian, karena mereka terbiasa hanya mempersiapkan telinga untuk belajar tanpa tahu bagaimana caranya mencari sampai meramu sebuah informasi. Jadi, tidak heran apabila diberikan kepadanya sebuah tugas yang mengharuskan untuk menyintesis sebuah informasi, yang dikumpulkan hanya seperti memindahkan sumber ke tempat yang lain dengan dipertautkan atau dijahit dengan sumber yang lain tanpa dimaknai dengan hasil pemikirannya sendiri. Fenomena ini merupakan miniatur yang menggambarkan secara jelas tentang bagaimana tingkat literasi anak didik (dalam hal ini mahasiswa).

Kendala-kendala yang telah dihadirkan di atas, diperparah lagi dengan kenyataan bahwa keterampilan meliterasi media tidak selalu terintegrasi dengan mata kuliah yang diajarkan (tergantung dosennya). Media hanya dijadikan sebagai bahan bantu mengajar saja, bukan sebagai salah satu sumber belajar. Hal ini disebabkan karena minimnya fasilitas dan performance dosen yang kadang "jauh" dari media.

Padahal, bergelut dengan berbagai media dan menjadikannya sebagai sumber belajar banyak sekali informasi yang dapat ditimba dan digali darinya. Agar dalam pemanfaatannya menjadi efektif dan efisien, dibutuhkanlah kemampuan yang baik dalam membaca, menulis, serta kemampuan untuk mengkomunikasikan secara komprehensif, informasi yang didapat dari berbagai media yang ada, selanjutnya disebut dengan literasi media dan informasi.

Kemampuan literasi media dan informasi wajib dimiliki mahasiswa, jika mereka tidak mau ketinggalan dan menjadi "asing" di masyarakat yang telah dikelilingi informasi ini. Dengan dimilikinya dua kemampuan tersebut pada diri mahasiswa, akan memudahkan mereka untuk merealisasikan slogan "lifelong education". Selain itu juga, keterampilan untuk meliterasi media dan informasi adalah salah satu strategi utama yang dikumandangkan UNESCO untuk dilaksanakan dalam proses pembelajaran. Hal ini semakin memperkuat lagi keharusan memiliki kedua keterampilan ini, karena kedua keterampilan literasi ini banyak diproyeksikan para ahli sebagai 21st century skills yang dapat dijadikan password untuk dapat melenggang dengan sukses dalam masyarakat informasi.

Pendapat di atas senada dengan pernyataan Dan Blake tentang alasan perlunya mengajarkan media literasi pada mahasiswa, yaitu (1) kita hidup ditengah lingkungan bermedia, (2) literasi media menekankan pada pemikiran kritis, (3) menjadi literat terhadap media merupakan bagian dari pembelajaran terhadap warga negara, (4) dengan mempunyai literasi terhadap media membuat kita dapat berperan aktif dalam lingkungan yang dipenuhi dengan media, (5) pendidikan media membantu kita dalam memahami teknologi komunikasi, dan (6) literasi media sudah terintegrasi dalam area $\mathrm{K}-12$.

Berdasarkan hal di atas maka dapat dirumuskan suatu permasalahan, sebagai berikut. Bagaimanakah tingkat literasi mahasiswa Fakultas Ilmu Pendidikan Universitas Negeri Jakarta terhadap media dan informasi (media and information literacy) ?

\section{KAJIAN TEORITIS}

\section{Literasi Media}

Istilah literasi media diciptakan pertengahan tahun 2004 untuk menggabungkan literasi lainnya dengan visual (Ofcom, 2004). Ofcom mengatakan literasi adalah keterampilan untuk mengakses, menganalisis, mengevaluasi dan sekaligus mengkomunikasikannya dalam berbagai macam format. Lebih daripada itu adalah mampu mengenali dan mengerti informasi secara komprehensif untuk mewujudkan cara berpikir kritis, seperti tanya jawab, menganalisa dan mengevaluasi informasi itu.

Wikipedia, the free encyclopedia (2007), menyebutkan bahwa media literacy adalah keterampilan untuk memahami sifat komunikasi, khususnya dalam hubungannya dengan telekomunikasi dan media massa (http://www.en.wikipedia.org/wiki/Literacy). Konsep ini diterapkan pada beragam gagasan 
yang berupaya untuk menjelaskan bagaimana media menyampaikan pesan-pesan mereka, dan mengapa demikian.

Media literacy di Indonesia lebih dikenal dengan istilah Melek Media. Potter dalam bukunya yang berjudul "Media Literacy" (http://www.kidia.org/ news/tahun/2007/bulan/05/tanggal/10/id/19/) mengatakan bahwa media literacy adalah sebuah perspektif yang digunakan secara aktif ketika individu mengakses media dengan tujuan untuk memaknai pesan yang disampaikan oleh media. Jane Tallim menyatakan bahwa media literacy adalah kemampuan untuk menganalisis pesan media yang menerpanya, baik yang bersifat informatif maupun yang menghibur (dalam http://www.kidia.org/news/tahun/2007/ bulan/05/tanggal/10/id/19/).

Rubin (dalam http://www.kidia.org/news/ tahun/2007/bulan/05/tanggal/10/id/19/) menawarkan tiga definisi mengenai media literacy yang berhasil dirangkumnya. Pertama, dari National Leadership Conference on Media Literacy yaitu kemampuan untuk meng-akses, menganalisis, mengevaluasi dan mengkomuni-kasikan pesan. Kedua, dari ahli media, Paul Messaris, yaitu pengetahuan tentang bagaimana fungsi media dalam masyarakat. Ketiga, dari peneliti komunikasi massa, Justin Lewis dan Shut Jally, yaitu pemahaman akan batasan-batasan budaya; ekonomi; politik; dan teknologi terhadap kreasi, produksi, dan transmisi pesan. Rubin juga menambahkan bahwa definisi-definisi tersebut menekankan pada pengetahuan spesifik, kesadaran, dan rasionalitas, yaitu proses kognitif terhadap informasi. Fokus utamanya adalah evaluasi kritis terhadap pesan. Media literasi merupakan sebuah pemahaman akan sumber-sumber dan teknologi komunikasi, kode-kode yang digunakan, pesan-pesan yang dihasilkan serta seleksi, interpretasi, dan dampak dari pesan-pesan tersebut.

\section{Elemen-Elemen Literasi Media}

Terdapat dua pandangan mengenai media literacy yaitu dari Silverblatt dan Potter (http:// www.kidia.org/news/tahun/2007/bulan/05/ tanggal/10/id/19/). Silverblatt menyatakan bahwa seseorang dikatakan memiliki keterampilan literasi media apabila dirinya memuat faktor-faktor, sebagai berikut.

1) Sebuah kesadaran akan dampak media terhadap individu dan masyarakat.

2) Sebuah pemahaman akan proses komunikasi massa.

3) Pengembangan strategi-strategi yang digunakan untuk menganalisis dan membahas pesan-pesan media.

4) Sebuah kesadaran akan isi media sebagai 'teks' yang memberikan wawasan dan pengetahuan ke dalam budaya kontemporer manusia dan diri manusia sendiri.

5) Peningkatan kesenangan, pemahaman dan apresiasi terhadap isi media.

Di sisi lain, Potter (http://www.kidia.org/ news/tahun/2007/bulan/05/tanggal/10/id/19/) memberikan pendekatan yang agak berbeda dalam menjelaskan ide-ide mendasar dari media literacy, yaitu. 1) Sebuah rangkaian kesatuan, yang bukan merupakan kondisi kategorikal.

2) Media literacy perlu dikembangkan dengan melihat tingkat kedewasaan seseorang.

3) Media literacy bersifat multidimensi, yaitu domain kognitif yang mengacu pada proses mental dan proses berpikir, domain emosi yaitu dimensi perasaan, domain estetis yang mengacu pada kemampuan untuk menikmati, memahami dan mengapresiasi isi media dari sudut pandang artistik, dan domain moral yang mengacu pada kemampuan untuk menangkap nilai-nilai yang mendasari sebuah pesan.

4) Tujuan dari media literacy adalah untuk memberi kita kontrol yang lebih untuk menginterpretasi pesan.

\section{Literasi Informasi}

Literasi informasi terdiri dari dua kata, yakni literasi dan informasi. Secara sederhana, literasi dapat diartikan sebagai kemampuan membaca dan menulis atau dengan kata lain melek aksara. Dari kedua macam definisi sederhana tadi, maka dapat diambil kesimpulan bahwa literasi informasi adalah kemampuan untuk mencari, mempelajari, dan memanfaatkan berbagai sumber informasi dalam berbagai bentuk. Istilah literasi informasi juga dapat disamakan dengan istilah 'melek informasi'.

Dalam CILIP dikemukakan bahwa literasi informasi adalah keterampilan untuk mengetahui kapan dan mengapa kita membutuhkan sebuah informasi; di mana mendapatkannya; serta bagaimana cara mengevaluasi, menggunakan, dan mengkomunikasikannya dengan tata cara yang benar (http://rettamd.blogspot.com/).

Sedangkan menurut APISI, "literasi informasi adalah seperangkat keterampilan untuk mendapatkan jalan keluar dari suatu masalah yang ada. Keterampilan ini mencakup keterampilan mengidentifikasi masalah, mencari informasi, menyortir, menyusun, memanfaatkan, mengkomunikasikan, dan mengevaluasi hasil jawaban dari pertanyaan atau masalah 
yang dihadapi tadi" (http:/ / rettamd.blogspot.com/).

\section{Keterampilan Literasi Informasi}

Seseorang dikatakan memiliki keterampilan literasi informasi jika memiliki keterampilan, sebagai berikut.

1. Mengetahui kebutuhan akan informasi

Dalam tahap ini, seseorang tahu bahwa sebuah informasi diperlukan; kenapa informasi tersebut diperlukan, apa yang diperlukan dari sebuah informasi (berapa banyak dan seperti apa) dihubungkan dengan batasan-batasan yang ada (seperti waktu, bentuk, finansial, dan akses); dan mengenali bahwa informasi itu tersedia di suatu cakupan luas dari bentuk-bentuk dalam berbagai lokasi-lokasi maya dan geografis.

Informasi bisa tersedia secara tertulis (buku, acuan bekerja, jurnal-jurnal, surat kabar, surat kabar, dan lain-lain), secara digital (CD-ROMs, internet atau World Wide Web, DVDs, komputer, website pribadi, dan lain-lain), melalui media yang lain, seperti siaran atau film atau dari seorang rekan kerja atau teman.

Intinya dalam tahap ini, seseorang sudah dapat mengambil keputusan yang tepat saat membutuhkan informasi, dengan cara mencari informasi dari tempat terdekat, cepat, dan mudah.

2. Mengetahui di mana sumber informasi

Dalam tahap ini, seseorang sudah dapat mengidentifikasi apakah sumber dari informasi tersebut dapat dieksploitasi atau digunakan, mengetahui di mana informasi tersebut tersedia, mengetahui bagaimana cara mengaksesnya, mengetahui baik buruk individu yang menjadi narasumbernya, kapan informasi tersebut sesuai digunakan, dan apa yang menjadi perbedaan di antaranya, sebagai contoh artikel jurnal ada yang tersedia dalam bentuk tercetak, elektronik, dan ataupun sebagai database saja.

3. Memahami bagaimana memperoleh informasi

Dalam tahap ini, seseorang sudah memiliki keterampilan untuk dapat mencari informasi secara cepat dari berbagai sumber yang terkait dengan pencarian. Selain itu, dalam tahap ini seseorang sudah memiliki strategi kapan harus mulai dan mengakhiri pencarian informasi hanya dengan membaca sekilas sebuah sumber informasi. Intinya dalam tahap ini, seseorang sudah memiliki keterampilan "purposive searching".

4. Memiliki pemahaman tentang kebutuhan untuk mengevaluasi hasil temuan informasi

Dalam tahap ini, seseorang sudah mempunyai kesadaran untuk mengecek keakuratan, keaslian, ataupun apakah isi dari informasi tersebut dapat di- dipertanggungjawabkan (dengan kata lain tidak menyesatkan).

5. Mengetahui bagaimana cara untuk bekerja dengannya atau mengolah informasi yang didapat

Dalam tahap ini, seseorang sudah tahu bahwa untuk memahami sebuah informasi, terlebih dahulu harus memaknai dan mengolah informasi yang didapatnya. Cara yang biasa digunakan adalah dengan membandingkan, mengkombinasikan, menambah catatan, dan menerapkan (penggunaan) informasi ditemukan. Selanjutnya, berakhir dengan keputusan apakah perlu mencari informasi tambahan atau tidak.

6. Memiliki etika dan tanggung jawab dalam penggunaannya

Dalam tahap ini, seseorang sudah memiliki etika dan rasa tanggung jawab yang tinggi dalam setiap menggunakan informasi yang diperolehnya. Salah satu caranya, yaitu dengan mencantumkan sumber asal informasi tersebut diperoleh. Hal ini untuk menjauhkan plagiat dan ketidakadilan dalam menggunakan informasi.

7. Memiliki pemahaman tentang bagaimana caranya mengkomunikasikan atau membagi apa yang telah ditemukan

Dalam tahap ini, seseorang sudah mengetahui sekaligus memahami bagaimana caranya mengkomunikasikan informasi yang didapatkan secara benar. Selain itu, seseorang dalam tahap ini sudah memiliki kemampuan menyintesis (lebih dari sekedar analisis) dan selanjutnya dapat menginformasikannya dalam format diseminasi yang sesuai.

8. Memiliki pemahaman tentang bagaimana mengelola sebuah temuan

Dalam tahap ini, seseorang sudah mengetahui sekaligus memahami bagaimana caranya menyimpan dan mengatur informasi yang sudah diperolehnya dengan menggunakan metode-metode yang paling efektif. Hasil temuannya tersebut dapat mencerminkan proses berpikir kritisnya dalam mengolah dan meramu kembali semua informasi yang telah diperolehnya.

Jadi, seseorang yang memiliki tingkat literasi informasi yang tinggi mengetahui lebih dari hanya sekedar bagaimana memperoleh informasi. Mereka juga memahami batasan-batasan dan kebutuhan untuk menguji bagaimana menggunakan informasi dan memahami bagaimana caranya mengatur serta mengkomunikasikan informasi. Informasi melek huruf adalah satu keterampilan terpisah dan sangat penting bagi orang-orang yang setiap harinya selalu bergulat dengan informasi. 


\section{METODOLOGI PENELITIAN}

Metode yang digunakan dalam penelitian ini adalah metode survey. Pendekatan yang dilakukan adalah bersifat deskriptif yaitu penelitian yang diarahkan untuk memberikan gejala-gejala, fakta-fakta, atau kejadian-kejadian secara sistematis dan akurat mengenai sifat-sifat populasi atau daerah tertentu.

Populasi penelitian ini adalah mahasiswa $\mathrm{Fa}$ kultas Ilmu Pendidikan terhitung mulai angkatan 2004 yang terdiri dari Jurusan Psikologi Pendidikan, Bimbingan Konseling, Teknologi Pendidikan, Pendidikan Luar Sekolah, Pendidikan Luar Biasa, Pendidikan Anak Usia Dini, Manajemen Pendidikan, Pendidikan Guru Taman Kanak-Kanak, dan Pendidikan Guru Sekolah Dasar.

Kemudian, dari populasi diambil sampel sejumlah 150 mahasiswa dengan meng-gunakan teknik quota sampling dan insidental sampling. Data dijaring dengan menggunakan instrumen kuesioner/ angket.

Data yang telah terjaring dihimpun dan didistribusikan dalam bentuk tabel dengan perhitungan analisis secara deskriptif dengan bantuan program komputer SPSS (Statistical Program for Social Science) versi 10.0, selanjutnya interpretasi dijabarkan dalam bentuk uraian.

\section{HASIL PENELITIAN}

Subjek dalam penelitian ini berjumlah 149 mahasiswa. Dengan gambaran laki-laki berjumlah 37 mahasiswa dan perempuan berjumlah 112 mahasiswa. Mereka terdiri dari berbagai jurusan yang ada di Fakultas Ilmu Pendidikan dengan rincian: 31 mahasiswa dari Jurusan Psikologi Pendidikan (PP), 22 mahasiswa dari Jurusan Bimbingan Konseling (BK), 22 mahasiswa dari Jurusan Tekonologi Pendidikan (TP), 22 mahasiswa dari Jurusan Pendidikan Luar Sekolah (PLS), 27 mahasiswa dari Jurusan Pendidikan Luar Biasa (PLB), 14 mahasiswa Jurusan Manajemen Pendidikan (MP), dan 11 dari Jurusan Pendidikan Anak (PA).

Berdasarkan angkatan terdiri dari tiga angkatan dengan sebaran 12 mahasiswa angkatan 2004, 55 mahasiswa angkatan 2005, dan 82 dari angkatan 2006. Selanjutnya, gambaran umum tentang subjek penelitian secara jelas akan diuraikan pada tabel berikut ini.

\section{Berdasarkan Jenis Kelamin}

Tabel 1. Gambaran Umum Subjek Penelitian Berdasarkan Jenis Kelamin

\begin{tabular}{|l|c|}
\hline \multicolumn{1}{|c|}{ Jenis Kelamin } & Jumlah \\
\hline Laki-Laki & 37 \\
\hline Perempuan & 112 \\
\hline & Total $=149$ \\
\hline
\end{tabular}

\section{Berdasarkan Jurusan}

Tabel 2. Gambaran Umum Subjek Penelitian Berdasarkan Jurusan

\begin{tabular}{|c|c|}
\hline Jurusan & Jumlah \\
\hline PP & 31 \\
\hline BK & 22 \\
\hline TP & 22 \\
\hline PLS & 22 \\
\hline PLB & 27 \\
\hline MP & 14 \\
\hline PA & 11 \\
\hline & Total $=149$ \\
\hline
\end{tabular}

\section{Berdasarkan Angkatan}

Tabel 3. Gambaran Umum Subjek Penelitian Berdasarkan Angkatan

\begin{tabular}{|c|c|}
\hline Angkatan & Jumlah \\
\hline 2004 & 12 \\
\hline 2005 & 55 \\
\hline 2006 & 82 \\
\hline & Total $=149$ \\
\hline
\end{tabular}

\section{Tingkat Literasi Mahasiswa terhadap Media (Media Literacy)}

Literasi media adalah salah satu keterampilan yang harus dimiliki seseorang dalam era globalisasi. Dikatakan demikian, karena dalam era tersebut manusia akan semakin sering bersinggungan dengan media. Baik itu untuk menambah wawasan atau pengetahuan maupun hanya untuk sekedar sebagai sarana hiburan pelepas penat saja.

Ada lima hal yang disoroti dalam keterampilan literasi media ini, mulai dari kesadaran individu atau masyarakat terhadap dampak media sampai dengan bagaimana individu atau masyarakat memposisikan dan mengapresiasikan media dalam kehidupannya sehari-hari.

Perspektif Ilmu Pendidikan - Vol. 19 Th. X April 2009 
Kehadiran ragam media yang mulai memadati segala bidang kehidupan manusia ditanggapi positif oleh sebagian besar responden. Walaupun begitu, mereka pun sadar bahwa kehadiran media juga tidak terlepas dari dampak negatifnya. Mereka juga beranggapan, media memiliki peran strategis dalam proses komunikasi khususnya komunikasi massa. Ditarik kesimpulan demikian, karena hampir seluruh responden menyatakan bahwa informasi yang terkandung dalam media massa dapat membantu terjadinya komunikasi di antara masyarakat dan media juga dapat membentuk suatu opini tertentu di tengahtengah masyarakat tentang berbagai hal.

Seseorang yang memiliki keterampilan literasi media tidak akan langsung mempercayai sebuah berita sebelum memeriksanya dengan sumber lain. Hal yang biasa dilakukan adalah memilih media yang diakui kredibilitasnya, memeriksa keakuratan berita dengan sumber lain, dan akan selalu mencari kelengkapan suatu berita yang didengarnya dari orang lain di dalam suatu media massa. Bila dibandingkan dengan ketiga hal tersebut, hampir setengah dari jumlah responden tidak memeriksa ulang terhadap berita yang telah didapatnya.

Seperti yang telah disampaikan sebelumnya, selain memiliki dampak negatif, media juga memiliki banyak dampak positif. Kata yang paling mudah untuk menggambarkan dampak positif dari media adalah "gudang informasi". Dengan adanya media, individu atau masyarakat terbantu dalam hal mengembangkan wawasan dan pengetahuannya. Ini dibuktikan, lebih dari setengah responden menyatakan merasa tidak nyaman bila tidak berhubungan dengan media walaupun hanya satu hari. Tetapi, bukan berarti mereka hanya menghargai pendapat/hasil karya orang lain yang ditampilkan dalam media massa saja karena beragam media dan corak yang muncul saat ini telah mampu menambah pemahaman mereka tentang peristiwa yang sedang menggejala di dunia ini.

Ironinya hampir sebagian besar responden (96\%) membaca atau menonton media massa hanya sebagai salah satu hiburan bukan untuk mencari informasi. Mereka pun tetap menghargai isi media tersebut, walaupun tidak menyukai gaya penyampaiannya.

Pembahasan di atas bila dilandasi pendapat Ofcom (2004), secara sederhana dapat digambarkan bahwa individu yang telah memiliki keterampilan literasi media mempunyai kemampuan untuk mengakses, menganalisis, mengevaluasi, dan sekaligus mengkomunikasikannya dalam berbagai macam format. Lebih daripada itu, mereka juga mampu mengenali dan mengerti informasi secara komprehensif untuk mewu- judkan cara berpikir kritis, seperti tanya jawab, menganalisis, dan mengevaluasi informasi itu.

Dengan menggabungkan antara keadaan lapangan dengan teori yang sudah dijabarkan, dapat ditarik suatu kata bahwa keterampilan mahasiswa terhadap literasi media tidak begitu mengkhawatirkan karena mereka sudah mempunyai kemampuan untuk mengakses, berpikir kritis untuk melihat dampak yang menyertai kehadiran sebuah media, sampai dengan mampu mengenali dan mengerti keakuratan sebuah informasi/berita (dengan melakukan kroscek dengan media lainnya). Namun, yang menjadi catatan dan sangat disayangkan masih banyak yang memposisikan atau melakukan kegiatan bermedia massa hanya untuk hiburan semata. Jadi, secara ekstrem bisa dikatakan, bahwa penambahan wawasan atau pengetahuan hanya dijadikan sebuah bonus atau efek dari tujuan utamanya, yaitu hiburan.

\section{Tingkat Literasi Mahasiswa Terhadap Informasi (Information Literacy)}

Keterampilan literasi terhadap informasi harus sejalan dengan keterampilan literasi terhadap media. Dikatakan harus sejalan, karena dalam proses perjalanannya antara media dan informasi saling terkait. Media adalah sarana untuk pencarian informasi dan sebaliknya, informasi akan mudah tersampaikan kalau melalui jasa sebuah media.

Individu bisa dikatakan memiliki keterampilan literasi informasi apabila ia sudah tahu akan kebutuhan informasi sampai paham bagaimana caranya mengatur informasi yang telah ditemukannya.

Mengetahui akan kebutuhan informasi dalam diri seorang individu yang pertama adalah seberapa seringnya mencari sebuah informasi dan apakah informasi yang dicari hanya sebatas perintah ataukah memang karena adanya kesadaran penuh akan artinya sebuah informasi. Dari hasil survei, tergambar $61.3 \%$ responden sudah mengakses informasi setiap hari dan hanya $32 \%$ responden yang menyatakan, mereka mencari informasi hanya untuk sekedar memenuhi kewajiban saja (dalam hal ini penyelesaian tugas) dan 37,3\% responden menyatakan informasi yang mereka cari berkaitan dengan bidang pendidikan. Dari data ini, ada dua kemungkinan yang muncul, pertama, memang mereka menyukai pendidikan dan yang kedua, berhubung tempat mereka bernaung adalah Fakultas Ilmu Pendidikan, maka tugas yang diberikanpun sedikit banyaknya menyerempet ke bidang pendidikan juga. Rata-rata dari mereka memperoleh informasi melalui media dalam bentuk digital (44.7\%) dan paper (44.0\%).

Mengetahui sumber, belum tentu individu pa- 
ham bagaimana memperoleh sebuah informasi. Cara yang bisa dilakukan untuk melihat tingkat kepahaman seseorang dalam mencari informasi adalah memilih sumber yang mudah untuk diakses/jangkau, melihat judul sumber bisa dijadikan sebagai hal tercepat yang dapat dijadikan alasan pencarian informasi, dan berusaha untuk terus mencari ke sumber yang lain bila belum menemukan informasi yang diinginkan. Ketiga hal yang diungkapkan sebelumnya, adalah tingkatan teratas yang dipilih para responden untuk menyatakan kepahamannya dalam memperoleh sebuah informasi.

Selain paham memperoleh, individu juga harus paham bagaimana mengevaluasi sebuah informasi yaitu dengan jalan melihat waktu pembuatannya dan mencari tahu tingkat keakuratan informasi yang diperoleh tersebut (hampir semua responden menyatakan telah melakukan hal tersebut dalam rangka mengevaluasi sebuah informasi).

Informasi yang telah didapat dari suatu sumber, hendaknya tidak ditelan ataupun diadopsi mentahmentah. Sebelumnya, kita harus mengolahnya terlebih dahulu dengan cara mencari kaitan di antara beragam informasi yang diperoleh (triangulasi) dan menambah masukan dari informasi lainnya (hampir seluruh responden menyatakannya demikian).

Kesadaran akan etika dalam mencari dan mengemukakan sebuah informasi dari responden sudah ada, terbukti sebanyak 130 responden $(86.7 \%)$, menyatakan mencantumkan nama narasumber saat mengutip pendapatnya. Sebanyak $54.0 \%$ responden menyatakan selalu mengkomunikasikan secara utuh/tanpa dipotong suatu pendapat/teori tertentu yang berhasil diperolehnya. Selanjutnya, informasi yang telah mereka temukan akan disampaikan kembali kepada orang lain, setelah sebelumnya mencari tahu tingkat kebenaran informasi dengan membandingkan dengan sumber lain yang sejenis.

Dalam CILIP dikemukan bahwa literasi informasi adalah keterampilan untuk mengetahui kapan dan mengapa kita membutuhkan sebuah informasi, di mana mendapatkannya, bagaimana cara mengevaluasinya, menggunakan, dan mengkomunikasikannya dengan tata cara yang benar (http:/ / rettamd.blogspot.com/).

Bila dilihat dari hasil yang telah didapat, ratarata keterampilan mahasiswa terhadap literasi informasi masih sebatas sampai keterampilan bagaimana memperoleh informasi, ditambah dengan tahapan terakhir yaitu mengelola sebuah temuan informasi, sedangkan tahapan yang berada di antaranya masih sedikit terlupakan dan terkesampingkan dalam pelak- sanaannya. Jadi bila ditarik kesimpulan, kemampuan mahasiswa terhadap literasi informasi belum penuh ataupun sempurna, karena ada beberapa tahapan penting dalam pencarian sebuah informasi yang masih sedikit terlupakan.

\section{KESIMPULAN}

Secara umum kesimpulan yang didapat dari penelitian ini adalah bahwa belum semua mahasiswa memiliki keterampilan dalam hal literasi media dan informasi. Bila sudah memiliki keterampilan tersebut, tidak semua tahapan (khususnya literasi informasi) dilalui/dijalani secara sempurna (ada beberapa tahapan yang secara tidak sengaja agak sedikit terkesampingkan).

Secara khusus penelitian ini menghasilkan kesimpulan, sebagai berikut. Pertama, dengan menggabungkan antara keadaan lapangan dengan teori yang sudah dijabarkan, dapat ditarik suatu kata bahwa keterampilan mahasiswa terhadap literasi media tidak begitu mengkhawatirkan. Mereka sudah mempunyai ke-mampuan untuk mengakses, berpikir kritis untuk melihat dampak yang menyertai kehadiran sebuah media, sampai dengan mampu mengenali dan mengerti keakuratan sebuah informasi/ berita (dengan melakukan kroscek dengan media lainnya). Namun, yang menjadi catatan dan sangat disayangkan masih banyak yang memposisikan atau melakukan kegiatan bermedia massa hanya untuk hiburan semata. Jadi secara ekstrem bisa dikatakan, bahwa penambahan wawasan atau pengetahuan hanya dijadikan sebuah bonus atau efek dari tujuan utamanya, yaitu hiburan.

Kedua, bila dilihat dari hasil yang telah didapat, rata-rata keterampilan mahasiswa terhadap literasi informasi masih sebatas sampai keterampilan bagaimana memperoleh informasi, ditambah dengan tahapan terakhir yaitu mengelola sebuah temuan informasi, sedangkan tahapan yang berada di antaranya masih sedikit terlupakan dan terkesampingkan dalam pelaksanaannya. Jadi bila ditarik kesimpulan, kemampuan mahasiswa terhadap literasi informasi belum penuh ataupun sempurna, karena ada beberapa tahapan penting dalam pencarian sebuah informasi yang masih sedikit terlupakan.

\section{DAFTAR PUSTAKA}

Anonymous. (2007). Pustakawan dituntut menguasai literasi informasi. Diakses pada tanggal 6 Februari 2007 dari http://rettamd.blogspot.com/

Perspektif Ilmu Pendidikan - Vol. 19 Th. X April 2009 
Astuti, S.I. (2007). Mendidik masyarakat cerdas di era informasi. Diakses pada tanggal 31 Juli 2007 dari http://literasimedia.wordpress.com/2007/07/ 20mendidik-masyarakat-cerdas-di-era-informasi/.

Bukhori, A. (2005). Menciptakan generasi literat. Diakses pada tanggal 31 Juli 2007 dari http://pribadi.or.id/diary/2005/06/22/menciptakan-generasi-literat/

Depkominfo. (2007). Informasi menjadi komoditas utama. Diakses pada tanggal 1 Februari 2007 dari www.depkominfo.go.id

Isnaini. Minat baca dan persepsi terhadap informasi. Diakses pada tanggal 31 Januari 2007 dari http:// imamisnaini.mul-tiply.com/journal/item/ 89?\&item_id=89\&view:replies=threaded.

Kidia. (2007). Fokus YPMA pengajaran pendidikan media. Diakses pada tanggal 31 Juli 2007 dari http:// www.kidia.org/news/tahun/2007/bulan/05/ tanggal/10/id/19/

Makarim, E. (2007). Krisis media dalam perspektif konvergensi telematika: Wacana media untuk penyempurnaan UU pers. Diakses pada tanggal 31 Januari 2007 dari http:/ / www.ristek.go.id/ index.php? $\bmod =$ News\&conf $=\mathrm{v} \& \mathrm{id}=21$
Ofcom. (2004). Review of ofcom's media literacy programme 2004-08. Diakses pada tanggal 31 Januari 2007 dari http:/ / www.ofcom.org.uk/ advice/media_literacy/review0408/

Riyanto, Y. (2001). Metodologi penelitian pendidikan. Surabaya:SIC.

Wardiana, W. (2002). Perkembangan teknologi informasi di Indonesia. Disampaikan pada Seminar dan Pameran Teknologi Informasi 2002 Fakultas Teknik UNIKOM. Jakarta.

Wikipedia. Literacy. Diakses pada tanggal 6 Februari 2007 dari http://www.en.wikipedia.org/wiki/ Literacy.

\section{KETERANGAN PENULIS}

Lussy Dwiutami Wahyuni lahir di Jakarta pada tanggal 25 September 1979. Saat ini, aktif menjabat sebagai dosen jurusan Psikologi, Fakultas Ilmu Pendidikan.

Evita Adnan, saat ini, aktif menjabat sebagai dosen jurusan Psikologi, Fakultas Ilmu Pendidikan. 